\title{
BRAZILIAN ENVIRONMENTAL-IMPACT ASSESSMENT SYSTEM: A CRITICAL ANALYSIS
}

\author{
PAULO ROBERTO A. TAGLIANI ${ }^{1}$, ROBERTA POHREN ${ }^{1} \&$ LUIS FERNANDO CARVALHO PERELLO ${ }^{2}$ \\ ${ }^{1}$ Federal University of Rio Grande, Brazil \\ ${ }^{2}$ FEPAM, Brazil
}

\begin{abstract}
Until recently, Brazil was recognized for having quite advanced environmental legislation. The Brazilian environmental licensing process was legally established in 1986. It provides for 3-phase licensing: pre-license, installation license and operating license. The environmental licensing is triggered by the environmental license application with the Environment Impact Assessment (EIA) authority. Depending on the regional location of the project or its polluting potential, the licensing may be conducted by the federal, state or local environmental agency, which makes the screening based on legislation to determine whether or not the environmental license requires an environmental impact study. There is a rule that defines those activities that will necessarily have to elaborate the EIA. After screening, the environmental agency establishes the Term of Reference. There is no scoping process in Brazilian law. Consequently, most environmental-impact studies lack a focus on core issues and sometimes shift their focus to less relevant issues, often disregarding the informal knowledge of the local population and their perception of risk. In addition, transparency as to the criteria employed in assessing the significance of impacts is generally lacking - studies that may biasedly disregard the potential for some harm are accepted. Originally, the first regulation established financial independence of the consulting company from the entrepreneur who is responsible for paying the expenses for the environmental studies. In the revision of this norm in 1997, this independence ceased to exist on the grounds that the necessary transparency was ensured through the application of the public-hearing instrument. However, the public hearing is a one-off event in the environmental-licensing process and does not adequately fulfill the role of promoting public participation, being an overly formal, bureaucratic and inhibiting process. In conclusion, the EIS process in Brazil has been of great relevance for environmental adequacy and/or minimization of project impacts, but there are still many weaknesses to strengthen to legitimize this important instrument.
\end{abstract}

Keywords: environmental licensing, public hearings, impact assessment, environmental impact studies.

\section{INTRODUCTION}

It is widely acknowledged that the EIA arose with the promulgation of the National Environmental Policy Act by the USA government in 1969, from which it became one of the most prevalent environmental policy instruments today [1]. Impact Assessment is the process of identifying, foreseeing, assessing, mitigating the relevant effects of biophysical and social order or others from projects or activities before important decisions are made [2]. Among the EIA effects concerning the projects, Ortolano and Sheperd (in Sánchez [3]) mention the removal of unfeasible projects, the legitimization of feasible projects, the choice for better location alternatives, the reformulation of plans and projects, the redefinition of purposes and responsibilities of the project proponents.

With the collective experience accumulated along 50 years of application of this management instrument, several authors have presented contributions, criticisms and recommendations for the improvement of EIA, such as Beanlands and Duinker [4], Canter and Canty [5], Erickson [6], Sadler [7], Lawrence [8], Pölönen et al. [9], Prenzel and Vanclay [10], Loomis and Dziedzi [11], Tagliani and Walter [12] and many others.

The International Association for Environmental Impact Assessment - IAIA in collaboration with the Institute of Environmental Assessment, UK [2] recommend a set of 
principles for the better practices of EIA according to which the study shall be: intentional, aware, rigorous, easily understood by the public, practical, relevant, efficient, focused, transparent, adaptive, participative, interdisciplinary, integrated, reliable, besides having a good cost-benefit ratio. The process shall be carried out with professionalism, severity, honesty, objectivity, impartiality and balance, and it should be susceptible to independent inspections. It is also recommended that the process should address the inter-relationships between the social, economic and biophysical aspects.

In the context of Environmental Impact Studies (EIS), the determination of the significance of the impacts is a fragile aspect that has been the subject of discussion and criticism in the international scientific community. There are no objective criteria for such determination, resulting in very subjective evaluations, generally determined by the analysts' experience and influenced by their professional profile.

According to Lawrence [8], usually for the determination of significance of the impacts, preliminary, partial and discursive approaches are still adopted, often limited to inconsistent ad hoc opinions. Besides this, the lack of focus in the EIS, examined by Beanland and Duinker [4] in Canada is also noticed in Brazil and in many other countries, therefore being one of the main challenges to be considered, as mentioned by Morrison-Saunders et al. [13]. Recently, Bond et al. [14] considered that EIA supports neoliberal agendas by facilitating economic development. Likewise, for assessments made in the Brazilian reality, Zhouri and Oliveira [15] highlight the context of uneven systems of power in the organization and exploration of the territories and their natural resources.

This article analyzes the process of environmental licensing in Brazil carried out through the EIS, based on bibliographic review and experience accumulated by authors in more than 20 years of work at a state agency of environmental licensing, consultancies and coordination of EIS.

\section{THE BRAZILIAN ENVIRONMENTAL IMPACT ASSESSMENT SYSTEM}

Although there was some regulation for the exploration of natural resources in Brazil since the 18th century [3], and that the state of Rio de Janeiro presented some regulation for the use of EIS since 1977 [16], the legal landmark of environmental protection in the country, as it occurs today, was set with the promulgation of the National Policy Law for the Environment in 1981. The structure of the Brazilian Environmental Policy - PNMA is a consulting and deliberative body - National Council for Environment (CONAMA), an executive body - National Institute for Environment (IBAMA), and the National Environmental System - SISNAMA. The last one is a structure formed in the three levels of government: federal, state and municipal. With the purpose of sharing the responsibility of environmental management among these federative bodies, PNMA establishes a set of principles and instruments for the environmental management in the country, among them, the Environmental Impact Assessment and the Environmental Licensing. The two PNMA instruments exist since 1981 with the promulgation of the National Policy Law for the Environment. This policy was detailed only in 1986, with CONAMA Resolution number 1, which had a significant change in 1997, revoking the article which provided that the environmental impact study should be carried out by a team non depending directly or indirectly on the project proponent. Such change enabled the advent of suspicions concerning the honesty of the process, taking into consideration the conflict of interests which is set in this new format. This resolution establishes the demand of EIS for activities considered as of significant impact for the environment, presenting a list of activities subject to EIS. Based on this list, the environmental agencies screen the projects that should be submitted to that rite of licensing. 
Similar to many countries, the Brazilian Environmental Policy and the Brazilian process of environmental licensing was inspired on the National Environmental Policy of the USA from 1969, which foresaw the Environmental Impact Study for Programs, Plans and Projects with potential harm for the environment. However, the Brazilian law limits the EIS only to projects, leaving out the analysis of programs and plans. On the whole, licensing occurs in three successive steps: one step considered as previous (Pre-license - LP), one step which meets the installation - the construction step, per se - (Installation license - LI) and the step in which the activity starts its operation (Operating license - LO). For some activities granting a Single license (SL) may be admitted or the granting of the Pre-license and the Installation license together, as it happens in mining processes. Yet, in case of EIS licensing, the activity always depends on the three licenses.

On a federal level, the Brazilian licensing agency, IBAMA, issued in the last 20 years (January 2000 to January 2020) more than nine thousand licenses, corresponding to an average of 500 licenses a year. The business sector criticizes environmental licensing in Brazil, stating that it a slow and inefficient process. Silva et al. [17] point out that the licensing agencies present a number of internal weaknesses resulting in delays for issuing licenses but, on the other hand, in many cases the entrepreneurs present inconsistent projects and fragile environmental studies, forcing them to complement such projects more than once along the process. In addition, some studies may be malicious, with a partial and biased view.

Faria [18] presents several aspects seen as weak in the environmental licensing process in Brazil, which include: communication failures with the society; failures in the model of execution of public hearings; the internal political conflicts in the agencies of the environmental sector; the increase of influence of subjective and ideological allegations; the judicialization of the decision-making process of enterprises, mainly motivated by the actions of the Public Prosecution and by the legal fragility of CONAMA resolutions, enabling legal protests; and the political demand and enforcement so that quick analysis of the so-considered priority projects take place.

We can also mention the lack of investments in the structure of environmental agencies, similarly to what happens in other sectors of the Brazilian public administration. We often find a fleet of scrapped vehicles compromising the regularity and the extent of inspections, little access to information technologies and data management and inadequate number of analysts. The judicialization of the licensing process is still rare, restricted to mega projects of development with large hydropower plants, mining and transposition of water basins.

In the studies we had the opportunity to know their content, we noticed that, in some cases, significant impacts are neglected, location and technological alternatives are not necessarily always alternatives as some are in fact unfeasible, inducing the choice of what has already been decided. In more extreme cases it has been possible to notice omissions of information or data distortion. Thus, due to the intending lack of robust technical characterizations that show the potential and/or effective impacts to be considered, some EIS are conducted as a simple protocol opportunity aimed only at the persuasion of the activity of interest, which makes them very distant from the intended nature.

The Brazilian legislation [19] stipulates the following steps for environmental licensing in cases that request the EIS: (1) the definition by the competent environmental agency, with the participation of the entrepreneur, the documents, projects and environmental studies needed for the start of the process, (2) requirement of the environmental license by the entrepreneur, with the documents, projects and relevant studies giving the due advertising, (3) analysis, by the competent agency, of the documents, projects and studies presented and the execution of technical inspections, (4) request for clarification and complementation by the environmental agency whenever necessary, (5) public hearing, (6) request for 
clarification and complementation by the competent environmental agency, resulting from public hearings, when applicable, (7) reiteration of the request for clarifications and complementation which had not been satisfactory, (8) issuing of conclusive technical opinion and, when applicable, legal opinion, (9) approval or refusal of the request for license giving it the due advertising.

Silva et al. [20] observed that an environmental license in the state of Rio de Janeiro could take 15 months to be granted, but there are rare processes which are processed in a shorter time. However, the term to obtain each of the licenses in the states ranges a lot and it may take many years to be concluded, depending on the term of the project execution, since an Operation License can only be issued after the installation of the project.

A research carried out by the National Industry Conference, in Brazil [21] pointed out the main complaints of the industrial sector in the licensing process. One of the highlighted points is that despite the integration between the states concerning the authorizing acts connecting the progress of the licensing to the obtainment of other authorizations such as the water allocation, there are no national criteria to rank the size and the polluting potential of the industries. In this case, a similar activity may have different procedures depending on the state where it is to be installed.

In conclusion, in the view of the Brazilian industrial sector, there is an excess of requirements along the whole licensing process, a lack of clarity in the regulation, a lack of preparation of the technicians from environmental agencies, an excess of restrictions, a lack of specific information concerning the process and studies required, and a lack of inspection.

However, analyzing 355 EIS of mining projects in Brazil, Oliveira and Andery [22] verified a high incidence of request for complementary information by the issuing agency. Much of the requested complementation was to respond to failures in the characterization of the enterprises or the engineering solutions, as well as the lack of maturity in the analysis of the environmental impact and its mitigating measures. The projects that did not need complementation obtained the environmental licensing in 285 days in average against the 569 days of those which had required complementation.

In the absence of a national standard to handle the size of enterprises and their polluting potential, some states weaken their criteria aiming at attracting industries and the consequent creation of jobs, and the increase of tax collection, leading to a dispute between the states. It must be observed that, these re-evaluations of framing of size and polluting potential, shall be approved after being discussed and subsidized with technical support in the Environment Councils of each of the federal states. These Councils should be organized equally with similar levels of representation of the different public agents, such as the following ones: public power, the academy, tertiary sector, industry, class associations, etc. Therefore, they constitute a space of political tension and disputes.

The Brazilian Federal Public Prosecution [23] presented a synthesis of the main weaknesses in the EIS submitted to analysis by this institution. Failures were pointed out in all steps of the EIS, since the non-compliance of the Term of Reference to the Environmental Programs and the Non Technical Report, including: presentation of illegitimate location or technological alternatives in order to justify the previously decided; comparison of alternatives as from differentiated base of knowledge; prevalence of economic aspects on environmental ones when choosing the alternatives and disregard of the water basin in the analysis of the impacts on the physical and biotic environment, negatively affecting the assessment of social and economic effects. Other failures pointed out include inadequate definitions concerning the area of influence of the projects, excluding environments and population segments which are part of the same sociocultural universe. They also pointed out 
insufficient field studies, area characterization based only on secondary data, lack of specific data integration, use of inadequate mapping scales.

Nowadays, an aggressive neoliberal agenda has been quickly implemented in the country, promoting the dismantling of the Brazilian environmental policy, aiming at "removing the obstacles" for the "economic development". Among them there is the change in the structure of the CONAMA, removing the participation of the civil society, revocation of articles of the legislation which granted special protection for certain ecosystems, presentation of draft legislation and constitutional amendments which aim at: simplifying the procedures for the granting of environmental licenses; facilitating the commercialization of pesticides, allowing mining and the exploration of water resources at indigenous areas, proposing the recategorization of protected areas facilitating access to the resources as well as fully revoking the National Policy of Sustainable Development of People and Traditional Communities, and others [24].

\section{THE PUBLIC HEARINGS}

The public hearing, in the scope of environmental licensing, is defined in Brazil since 1986 [25]. It consists of an administrative procedure provoked by the public power through a licensing agency but paid by the entrepreneur and it aims at informing the population about the project which is under licensing. The public hearings are part of the licensing of those activities which may cause a significant environmental impact. Therefore, they are held only in those cases they represent, numerically, the minority of all licensing granted in the country. The other licensing which are not considered as triggers of significant impact, that are not submitted to EIS and, therefore, are not also subject to public hearings.

The hearing has a simply advisory nature and it is part of the last step for licensing. That is, whenever a public hearing is held, the environmental agency has already received all the studies and, on its part, is ready to issue the license. And this practice of selecting comments only after the decision-making work is a reason for discontentment in the society [26].

As it happens, in the final step of the studies, a little before the license is issued and normally bringing unsatisfactory answers to the ones attending the hearings, this displeases some sectors of the civil society that defend intermediary hearings. These same sectors argue that holding meetings during the course of studies could avoid opening judicial proceedings, as it has commonly been happening in the licensing of mega-projects such as hydropower plants and mining plants. At least in the south of Brazil, some large-scale and controversial projects have had intermediary hearings despite being scheduled by the public prosecution.

There is a general complaint due to the lack of transparency where the affected communities by the project say they feel marginalized. The previous dissemination of project details, since its planning, could provide opportunity for the population to participate in the decision-making process. Even with the enforcement of the legislation, what we notice is the lack of a mechanism that considers the awareness of the communities in the characterization of the socio-environmental impacts of the enterprise. Thus Zhouri and Oliveira [15] and Silva et al. [20] point out failures in the planning of the hearings: centralized planning, limited participation, difficulties of access to information, marginalization in the public hearings and flaws in the regulation.

Flaws in the regulation can be exemplified by the difficulty the federal agency (IBAMA) has had to update and/or modernize the rules for the execution of public hearings. The first regulation arose with the CONAMA Resolution 9 from 1987 [27]. It has been, for at least ten years that the agency has been trying to update this legal device. The last attempt was through a public consultation that ended in July 2019, but the process has not advanced until the present moment and the regulation from 1987 still prevails. 
The new regulation which is being proposed brings an aspect that can result in more transparency in the relationships with the society. IBAMA may request the entrepreneur to arrange specific technical meetings with the city governments, leaders or communities of the areas of influence of the enterprise, especially with the social groups in situation of higher socio-environmental vulnerability that are impacted. Thus, the idea is to clarify the purpose of the hearing and stimulate comments, suggestions and criticisms to be presented during the public hearing. The advertising of the project submitted for licensing is also forbidden to avoid it influences or complicates the citizens to develop their own beliefs about the project.

It is quite rare that during a public hearing, unprecedented or significant aspects arise resulting in drastic modifications in the license to be issued. It is also not common that the simple result of the hearing causes delays or obstacles for the issuance of the license. The participation of the population in the hearing is political and it is normally summarized in the establishing of a scenario formed by a group of people favorable to the project and other opposing it. As a result, there rarely are usable issues to qualify the licensing. In very large projects, which attract the attention of NGOs and universities, the technical contributions are present, although it is possible to notice that there is very little use of such suggestions from these sectors.

Although there is no requirement for the hearing, it is often held. Public prosecutors require the hearing, very often even in towns neighboring the enterprise, provided that it is highlighted the environmental impacts will reflect in their territories [27].

At last, it is noticed that the public hearing in the environmental area is controversial. It consists of an instrument that needs to be improved to surely assure the democratic participation of the society. It has the proposal to be an opportunity for a broad debate and interchange of ideas between the different sectors of the society. However, in fact it is nothing but explanatory meetings presenting technical information in hermetic language. As a result, the discussions, when happening, they are considered insufficient and the arising manifestations are not used for the improvement of the process [28].

\section{CONCLUSIONS}

Environmental licensing in Brazil has been the object of great controversy. Criticisms come from both entrepreneurs and from public agencies (administrators and public prosecution), experts and the community. The implementation and the operation of enterprises that cause environmental impacts always imply social and economic conflicts, the mediation and distension and involve the construction of processes of decision-making that enable the participation of the society. Deciding about the future of everyone cannot be a task of a sector, or a group of technicians separately; such a decision should be made by the society with the necessary technical information for conscious decision-making [29]. First and foremost, it is a political, social and economic process of tension between the interests of the State - committed to attract development projects and then balance the finances to attend the short-term social demands, the private interests, the affected communities, which often receive an unequal portion of the project benefits in view of the risks they are submitted to - and part of the society concerned in assuring resources for the future generations including, in this case, sectors of the state itself as the academic world and licensing agencies NGOs and communities.

In order to avoid a waste of time with the demand of complementation by the licensing agencies, the conception of the projects must be based on strategic environmental planning, in which the options in location and technological alternatives were exhausted. To make IA a more effective and transparent instrument, the means of social participation, management and decision-making must be improved so that the ones involved and affected can have their 
effective participation assured. Alternatives for the qualification of environmental licensing process could include:

- The establishment of public hearing in all steps of the process, including scoping, previous, installation and operation licenses, with the groups positively and negatively affected by the enterprises.

- The setting of a board certified and independent environmental analysts for the analysis of the EIS, which would consist in the necessary exemption of EIS, characterized by the principle of intra and intergenerational equity.

- Establish in the Terms of Reference a limitation in the number of pages in the EIS in order to avoid unnecessary information that deviate the focus of the analyst to irrelevant issues, resulting in excessive demand of time by the environmental agencies as well as encumber the licensing system.

- Empower the licensing institutions aiming at a closer approximation with the scientific community and independent entities.

- Provide the environmental agency with the adequate material conditions and the human resources to execute more effectively its role of promoting the sustainable development, through a greater capacity of inspection, screening and processing of environmental data.

\section{REFERENCES}

[1] Banhalmi-Zakar, Z. et al., Evolution or revolution: Where next for impact assessment? Impact Assessment and Project Appraisal, 36(6), pp. 506-515, 2018.

[2] International Association of Impact Assessment, https://iaia.org/. Accessed on: 13 Dec. 2019.

[3] Sánchez, L.E., Avaliação de Impacto Ambiental: Conceitos e Métodos, São Paulo, 2006.

[4] Beanlands, G.E. \& Duinker, P.N., An Ecological Framework for Environmental Impact Assessment in Canada, Federal Environmental Assessment Review Office and Institute for Resource and Environmental Studies: Hull, QC and Halifax, NS, 1983.

[5] Canter, L.W. \& Canty, G.A., Impact significance determination: Basic considerations and a sequenced approach. Environmental Impact Assessment, 13, pp. 275-297, 1993.

[6] Erickson, P.A., A Practical Guide to Environmental Impact Assessment, Academic Press: San Diego, 1994.

[7] Sadler, B. (Canadian Environmental Assessment Agency/International Association for Impact Assessment), Environmental assessment in a changing world: Evaluating practice to improve performance. International Study of the Effectiveness of Environmental Assessment, ISBN: o-662-24702-7, Cat. No.: EN106-37/1996E, 1996.

[8] Lawrence, D.P., Impact significance determination: Designing and approach. Environmental Impact Assessment Review, 27, pp. 730-754, 2007.

[9] Pölönen, I., Hokkanen, P. \& Jalava, K., The effectiveness of the Finnish EIA system: What works, what doesn't, and what could be improved? Environmental Impact Assessment Review, 31, pp. 120-128, 2011.

[10] Prenzel, P.V. \& Vanclay, F., How social impact assessment can contribute to conflict management. Environmental Impact Assessment Review, 45, pp. 30-37, 2014.

[11] Loomis, J.J. \& Dziedzi, M., Evaluating EIA systems' effectiveness: A state of the art. Environmental Impact Assessment Review, 68, pp. 29-37, 2018.

[12] Tagliani, P.R.A. \& Walter, T., How to assess the significance of environmental impacts. WIT Transactions on Ecology and the Environment, vol. 215, WIT Press: Southampton and Boston, 2018. 
[13] Morrison-Saunders, A., Pope, J., Gunn, J.A.E., Bond, A. \& Retief, F., Strengthening impact assessment: A call for integration and focus. Impact Assessment and Project Appraisal, 32(1), pp. 2-8, 2014.

[14] Bond, A., Pope, J., Fundingsland, M., Morrison-Saunders, A., Retief, F. \& Hauptfleisch, M., Explaining the political nature of environmental impact assessment (EIA): A neo-Gramscian perspective. Journal of Cleaner Production, 244, 2020.

[15] Zhouri, A. \& Oliveira, R., Desenvolvimento, conflitos sociais e violência no Brasil rural: O caso das usinas hidrelétricas. Ambiente \& Sociedade, 10(2), pp. 119-135, 2007.

[16] Tommasi, L.R., Estudo de Impacto Ambiental, Editora CETESB: São Paulo, 1994.

[17] Silva, B.M.P., Cavalcanti, P.M.P.S., Rodrigues, M.G. \& Almeida, J.R., Analysis on the environmental permitting process in Rio de Janeiro. Revista Internacional de Ciências, 4(2), 2014.

[18] Faria, I.D., Ambiente e energia: Crença e ciência no licenciamento ambiental parte III: Sobre alguns dos problemas que dificultam o licenciamento ambiental no Brasil. www.meioambiente.mppr.mp.br/arquivos/File/Acervo/Ambiente_e_Energia_Licenci amento_Ambiental.pdf. Accessed on: Nov. 2019.

[19] CONAM̄M, Resolução no. 237 of 19 December 1997. Published on DOU no. 247, 22 December 1997, Session 1, pp. 30841-30843, 1997.

[20] Silva, R.H., Walter, T. \& Soto, W.H.G., A audiência pública no licenciamento ambiental: instância de democratização do processo ou de promoção do empreendimento? Diversidade Sociológica - Facetas da Pesquisa em Sociologia, 2, pp. 171-190, 2016.

[21] Confederação Nacional da Industria (CNI), Proposta da indústria para o aprimoramento do licenciamento Ambiental, 2013. https://bucket-gw-cni-static-cmssi.s3.amazonaws.com/media/filer_public/5c/d4/5cd43d44-29df-4cad-adfc-

2a9d264f65aeproposta_da_industria_para_o_aprimoramento_do_licenciamento_amb iental_1.pdf. Accessed on: 21 Jan. 2020.

[22] Oliveira, P.M. \& Andery, P.R.P., O processo de licenciamento ambiental no projeto de empreendimentos industriais de mineração. Gestão e Tecnologia de Projetos, 12(2), 2017.

[23] MPU, Deficiências em estudos de impacto ambiental Síntese de uma Experiência Brasília. Ministério Público Federal $4^{\mathrm{a}}$ Câmara de Coordenação e revisão, Escola Superior do Ministério Público da União: Brasilia, p. 48, 2014.

[24] Abessa, D., Famá, A. \& Buruaem, L., The systematic dismantling of Brazilian environmental laws risks losses on all fronts. Nature Ecology \& Evolution, 2019. DOI: $10.1038 / \mathrm{s} 41559-019-0855$.

[25] CONAMA, Resolução no. 1/1986 Published on DOU of 17 February 1986, Session 1, pp. 2548-2549, 1986.

[26] Chess, C. \& Purcell, K., Public participation and the environment: Do we know what works? Environmental Science \& Technology, 33(16), 1999.

[27] CONAMA, Resolução No. 009/1987, Data da legislação: 03/12/1987 Publicação DOU of 5 July 1990, p. 12945, 1990.

[28] Pinheiro, L. \& Trigueiro, A., Audiência pública como instrumento da política ambiental: Um balanço analítico. https://pdfs.semanticscholar.org/9cef/37b057b7874c786681e948ae094576ecf267.pdf. Accessed on: 25 Nov. 2020.

[29] Anello, L.F.S. \& Tagliani, P.R.A., O espaço da Educação Ambiental no licenciamento da área do porto do Rio Grande. Ambiente \& Educação (FURG), 10(1), pp. 129-147, 2005. 